Fecha de recepción: diciembre 2018

Fecha de aceptación: marzo 2019

Versión final: junio 2019

\section{The Heroine's Path. Teresa de la Parra: Charting the Path of Latin American Heroines}

RoseAnna Mueller*

\begin{abstract}
As a heroine in the novel of her own story, the Venezuelan author Teresa de la Parra (1889-1936), was an acknowledged noted novelist and gifted public speaker in her lifetime when she was invited to deliver three lectures in Bogotá and Barranquilla, Colombia, in 1930, and later in Cuba. The lectures were not published until 1961 in Caracas by the Venezuelan critic Arturo Uslar Pietri and I translated the lectures for the book, Teresa de la Parra: A Literary Life (Cambridge Scholars Publishing, 2012). The Tres Conferencias: Influencia de las mujeres en la formación del alma americana or Three Lectures: Women's Influence in the Formation of the American Soul, described the important roles women played during the Conquest, Colonial, and Independence eras in Latin America. The Colombian Lectures represent her last work. In the 1970's, when critics began to value women's writing for its valuable contribution to literature, they began to read and value this author's work that addressed female heroines.

In these lectures de la Parra declared herself a "moderate feminist" as she highlighted the important roles the founding mothers played in Latin American history and in the formation of its ethos and culture. She wanted to uncover the hardships that had been imposed on women starting with the conquest of México. As Spain conquered more of the Latin American continent, women played important roles, but de la Parra pointed out that the stories of half the human race had been ignored by Latin American historians, who tended to write about battles and victories rather than the sacrifices and the heroic contributions of women. By recuperating the voices of the "founding mothers," Queen Isabela, Nusta Doña Isabela (el Inca Garcilaso's mother) Doña Marina, Madre Castillo, Policarpa Salavarrieta, Manuela Sáenz and her contemporaries Delmira Augustini and Gabriela Mistral, de la Parra created a community of heroines.
\end{abstract}

Keywords: Teresa de la Parra - Feminist - Latin America - heroines.

[Resúmenes en inglés y portugués en las páginas 246 - 247]

${ }^{(*)}$ Ph.D., Faculty Emeritus, former coordinator of humanities and foreign languages at Columbia College Chicago. Participant in four National Endowment for the Humanities Seminars and Institutes, recipient of a Teaching/Research Fulbright Fellowship in Venezuela (2002-2003) and Colombia (2017). Book publications include Ana Isabel, A Respectable Girl (2016) and Teresa de la Parra: A Literary Life (2012). Publications and book reviews appear in The Hispanic Connection, Latin American Women Characters, A Twice-Told Tale: Reinventing the Encounter in Iberian/Iberian American Literature and Film, Latin America 
as its Literature, Women Characters in Latin American Literature, The Latin American Feminist Encyclopedia, Hispania, Letras Femeninas, and The Chicago Tribune.

The Venezuelan author Teresa de la Parra (1889-1936), was an acknowledged noted novelist and gifted public speaker in her lifetime. In her first novel, El Diario de una señorita que escribió porque se fastidiaba, or The Diary of a Young Lady who Wrote because she was Bored, the protagonist, María Eugenia writes to her friend Cristina that each of us is the heroine in the novel of our own stories. "You and I-all of us who, moving through the world, have some talents and some sorrows-are heroes and heroines in the novels of our own lives, which is nicer and a thousand times better than written novels" (Iphigenia $10)^{1}$. De la Parra was too modest to claim to be a heroine herself. Her life experience did not follow María Eugenia’s model as a young girl who sacrificed herself to society like her Greek namesake. María Fernanda Palacios, psychoanalyzed the protagonist as a product of her time in Ifigenia: Mitología de la Doncella Criolla (Iphigenia: The Mythology of a Creole Maiden.)

De la Parra's own struggle is best summed up in a letter she wrote to García Prada, who wanted to translate her second novel, Las memorias de Mama Blanca into English. The letter partially sums her heroine's journey.

I was born in Venezuela to a large family of six children. I spent most of my early childhood on a sugar plantation in Caracas. Many of the memories from my early childhood are contained in Mama Blanca's Memoirs. My father died when I was eight years old and my mother moved our family to a province in Spain to live near our maternal grandmother to be educated. Both my grandmother and mother belonged, in their outlook and in their customs, to the established colonial society of Caracas. Therefore, in my late childhood and adolescence I had a strict Catholic upbringing. Corpus Christi processions, Holy Week, Marian feast days, and other holy feast days of the Catholic Church, along with walks in the country, were my only celebrations and social outlets. I returned to Venezuela when I was eighteen years old. I spent a lot of time in the countryside reading as much as possible. It was in Caracas that I first came into contact with the world and society. I observed the continual conflict of the new mentality of young women who traveled and read, but who lived bound to old assumptions and to the customs of an earlier age. They were ruled by the old values but did not believe in them and longed, in their hearts, for an independent life and ideas, until they married, gave them up, and reverted to the old ideas, thanks to motherhood. This eternal female conflict with its end in renunciation gave me the idea for Iphigenia. Because the novel was critical of men and was opposed to established ideas, it was not well received in my country. Conservative Catholics in Venezuela and Colombia deemed the novel to be dangerous to young girls, since they enjoyed seeing themselves portrayed 
by the heroine with her aspirations and her limitations and sided with her. The novel was attacked and defended by both sides, which contributed to its readership. In 1923 I moved to Paris, and I have lived here since. In 1928 I wrote my second book, Mama Blanca's Memoirs, which, unlike Iphigenia, was very well received by the traditionalists but disappointed the female readers of Iphigenia, who missed María Eugenia Alonso, the heroine sacrificed to custom. I am currently studying colonial Latin American history, which I would like to write about some day (Obra 599-510).

De la Parra chronicled the many changes taking place in her homeland from a woman's point of view. Her work was groundbreaking insofar as her fiction created a space for women, and she refused to write in the dominant styles of the period. The author's limited body of work showcases her diversity and her depth. Iphigenia is a coming-of-age novel and a love story. Mama Blanca's Memoirs evokes a happy childhood and a dying way of life. Her lectures reveal her concern for the status of women in modern society as she summarized their influence and their roles in all Latin-American societies across the centuries. Due to her family's economic situation and the generosity of her patroness, she was able to live the life of a writer, traveling and participating in literary groups and giving talks on women's history and the need for their emancipation. She suffered because her work was misunderstood. Her writing served as a forum for women's rights. She was a precursor for the achievement of cultural androgyny and had hoped to provide role models for the future by promoting the lives of women who led worthy and notable lives in the past.

Iphigenia was immediately successful because it was readable and entertaining. It dared to attack the lives of the upper class and the colonial values to which they insisted on clinging to. Through her heroine, de la Parra spoke the unspoken, and said what needed to be said: Women in Latin America needed to find alternative models. De la Parra pushed the boundaries of Venezuelan society by questioning marriage as a legal contract and motherhood as the basis for sacrifice. The marriages in Iphigenia are examples of relationships based on economics, class expectations and appearances. They provide a scathing criticism of middle-class matrimonial practices. De la Parra took up the call to be a writer who would hold up a mirror to Venezuelan society and was called to task for it. She disappointed her family, who traced its ancestry to the conquistadors, and expected her to marry. Her conservative mother did not approve of her daughter writing, Instead, the young writer found a patron and protector in Emilia Ibarra, who would make it possible for her to travel and write. What the author did not state in her biographical sketch was the ordeal brought about by tuberculosis. There was no cure for this disease at the time, and de la Parra, at the advice several doctors undertook a series of painful procedures until she died of the disease in 1936, unable to write her third book, which would have been a historical biography of her hero Simón Bolívar. But it would have been told from the point of view of the women who inspired him.

Ana Teresa Parra Sanojo, who took the pen name Teresa de la Parra, was born on October 5, 1889 in Paris to a Venezuelan couple, the first daughter born to Rafael Parra Hernaíz and Isabel Sanojo Ezpelosin de Parra. She lived much of her life in Europe, but always considered herself to be Venezuelan, and such was her identification with Venezuela that 
in the letter to García Prada, she erroneously claimed that she was born there, whereas her birth certificate states that she was born in Paris. Today she is considered one of the most distinguished Venezuelan authors, and her works are based on her time spent in Caracas (Iphigenia, 1924), and her childhood on a hacienda near Caracas (Mama Blanca's Memoirs, 1929). She described her upbringing and her experiences in Venezuela in a new style free of the criollismo or picturesque style in vogue at the time.

Iphigenia was a success in Europe, where it was considered exotic and picturesque but it irked Venezuelan readers who interpreted de la Parra's descriptions as a mockery of their society. Furthermore, they were offended that it was written by a writer who they believed was unfamiliar with the customs of her own country, since the writer had lived abroad for several years. They neglected to understand, however, that de la Parra was a keen observer. Exposing the narrow-mindedness and hypocrisy in Venezuelan society while employing tongue-in-cheek humor and subtle irony, made her an outstanding social critic.

The criticism only served to create a clandestine following for Iphigenia. The initial attacks on de la Parra's morality hurt her, and she resented being identified with her heroine María Eugenia, whom she considered to be a weak character who gave in to societal demands. There was an attempt to stop Iphigenia's second printing. The hypocrisy, the backwardness, the machismo and the political situation in Venezuela had shocked her on her return to the country, and the author was taken to task for exposing them. She resisted both her family's pressure to marry as well as the pressure to be more militantly feminist. Perhaps she was unclear on the concept of feminism at the time, but she was clearly upset by the rampant machismo in Venezuela and looked for new models for women to live their lives. As Annis Pratt pointed out, "When a woman sets out to manipulate language, to create new myths out of old, to write an essay or paint a painting, she transgresses fundamental social taboos in that very act. the outcries evoked by the mildest of women writers who dared to make even the slightest rebellions against gender norms: to use our drives for authenticity in order to shape feminine archetypes into fiction, to bring elements of our inner world into consciousness and give them shape in the social form of the novel, is an act of defiance with perilous consequences. (Archetypal Patterns 11.)

Audacious, convincing and sincere in its outlook, Iphigenia is a reference point for understanding the feminine world of a young girl who struggles to fit in her society, questions its values, but succumbs to its demands. De la Parra's works penetrated into the deepest reaches of feminine identity and the search for women's universal worth. "If there is truly something worth telling in Teresa de la Parra's life, it lies in her personality, to whose independent flowering she first sacrificed social respectability and which, in the end and with vengeance, she sacrificed to the mystical ideal" (Lemaitre 213).

Not wanting to discuss her own success as an award-winning novelist when she was invited to deliver three lectures in Bogotá and Barranquilla, Colombia, in 1930, and later in Cuba, she chose to highlight the lives of women who had been neglected in history ${ }^{2}$. She considered these women to be heroines, and in some cases, martyrs. And it would not be a stretch to imagine that she identified in some part, with all of them. As the first Latin American author to receive a literary award in Europe, she was not content to rest on her laurels. As winner of the annual award given by Casa Editora Franco-Ibero-Americana in Paris in 1924, she received a prize of 10,000. French francs. Despite her celebrity status, 
she alerted her standing-room only audience that she was reluctant to talk about herself. Her examples and conclusions in the Three Colombian Lectures offered a sweeping view of women's roles in Latin American history, which amounted to consciousness-raising. María Antonia Palacios, de la Parra's Venezuelan biographer considers these lectures to be her best writing.

The lectures were not published until 1961 in Caracas by the Venezuelan critic Arturo Uslar Pietri and I translated them for my book, Teresa de la Parra: A Literary Life (Cambridge Scholars Publishing, 2012). The Tres Conferencias: Influencia de las mujeres en la formación del alma americana or Three Lectures: Women's Influence in the Formation of the American Soul, described the important roles women played during the Conquest, Colonial, and Independence eras in Latin America. The" Colombian Lectures" represent the author's last work and they reflect her interest in Latin American history, which she undertook to study on her own. As she stated many time in her letters, she regretted the opportunity to have a formal education, and she tried to make up for this by attending lectures, taking lessons in elocution and corresponding with intellectuals. In the 1970's, when critics began to value women's writing for its valuable contribution to literature, the lectures began to be read and better appreciated since this author's work addressed feminine subjects.

In these lectures de la Parra declared herself a "moderate feminist" as she highlighted the important roles the founding mothers played in Latin American history and in the formation of its ethos and culture. She wanted to highlight the hardships that had been imposed on women starting with the conquest of México. As Spain conquered more of the Latin American continent, women played important roles, but de la Parra pointed out that the stories of half the human race had been ignored by Latin American historians, who tended to write about battles and victories rather than the sacrifices and contributions of women. She wanted to recuperate the voices of the "founding mothers." The historical women de la Parra discussed in these lectures ranged from Queen Isabela, Ňusta Doña Isabela (el Inca Garcilaso's mother) Doña Marina, Madre Castillo, Policarpa Salavarrieta, and Manuela Sáenz. Early in the lectures she contrasted the lives of her contemporary writers Delmira Augustini and Gabriela Mistral. All were examples of women's contributions to Latin America. In their own way they challenged the status quo, and de la Parra wanted to bring the voices of these unsung women to her audience. Today, she is considered a model of Latin American feminist literature who inspired other women writers to write about their struggles. Antonia Palacios, Laura Arellano and Milagros Matas Gil and others can be counted among the Venezuelan writers who followed in her path.

The 1920's and 1930's produced several outstanding Latin America women poets: Delmira Augustini, Juana Ibarborou, Gabriela Mistral, and Alfonsina Storni, to name just a few of the most well-read ones, and the most frequently translated into English. Only de la Parra and the Chilean María Luisa Bombal are cited by literary historians as outstanding women novelists during the same period. Both authors provided an outlet for women's voices. Their heroines speak in the first person about themselves, and for themselves as they overcome demons, tests and enemies.

De la Parra created a starting point for other women writers who followed in her footsteps and a process through which female experience could be recorded. The process allowed for a production of a subtext through dissident discourse, and the insertion of the Latin 
American woman into the historical-social context. It legitimized the female as a subject. She began a literary tradition that reflects the subversive context of literature. Iphigenia is the motive text, the springboard that challenged the conventional order of seven decades, and integrated the participation of the woman-writer in the historical-social process of Latin America.

A key to understanding de la Parra's writing and her interest in promoting women's lives and concerns resides in her own idiosyncratic life. Unlike most women of her class and generation, she was economically independent, free to travel and devote her time to writing. After having written two successful novels and other fiction, de la Parra began to devote herself to studying Latin American history in order to recuperate women's roles in its development. De la Parra identified with her Venezuelan heritage and recalled stories she heard from her female relatives.

Her first opportunity to put her study to use came when she delivered her lectures, which aside from relying on accepted written history at the time, were infused with passion, biblical references to parables, and oral histories she outlined what she hoped would be her third novel. She had done the historical research, but wanted the novel to be different from the official version of Bolívar's biography, since it would include the perspectives of the women in his life and their influence on his career. Various biographies had been written about Bolívar, but de la Parra wanted her readers to experience history from a woman's point of view. She identified with Bolívar, who died of tuberculosis in his 40's, the same disease that would take her life in 1936 when she was forty-seven. We can deduce how she would have mined the historic record while inserted "When I traveled to Colombia in 1930, the public wanted to hear more confessions and were disappointed when instead I chose to speak about historical characters, Fanny de Villars, Doña Marina, Doña Manuelita, and Inca Garcilaso's mother" (Obra 630). The reading public adored confession and Iphigenia was popular in some circles because readers thought it was about her. She disabused her audience by stating, "I do not recognize myself in my novels. The first was written by a contemporary young girl whose address we don't know; the second was dictated by a dead grandmother who was hospitable and loving as are many women who live under their tile roofs, so that they are the absent authors of these stories or novels, in my way of thinking." She focused instead on the historical role women played during the Spanish conquest, through Latin America's colonial era and into the time of the wars of independence as she called to mind celebrated forgotten or marginalized heroines and women, she considered to be female martyrs, such Nusta Isabel, Inca Garcilaso de la Vega's mother and the role her own foremothers played during revolutionary times. Highlighting female achievements throughout Latin American history, she pointed to the need for more positive feminine role models, for she believed women decided the direction of human societies. Her feminist message was not strident, but rather tame and "moderate" to use her own term.

Her sense of history was not strictly historical; it was submerged in admiration for her heroines. She preferred to talk about daily occurrences, privileging every day, colloquial language and praised women for their gift of continuity and hailed them as the true founders of families and nations. She described the contribution of women's roles, and envisioned them of having many things in common no matter where they lived in Latin America. She relied on stories and fables to tell her version of history and idealized women who had been 
martyred, defeated or marginalized. In the lectures, de la Parra led her audience through a brief history, a kind of crash course, of women who played key roles in shaping Latin American history. To bring home that point that things had to change, she contrasted the lives of two contemporary poets: her friend Gabriela Mistral, the Chilean writer who would be awarded the NobelPrize in Literature in 1945, and the Chilean poet Delmira Augustini, who made a hasty marriage and was shot to death in a jealous rage by her former husband. Augustini suffered the same fate as the protagonist of Iphigenia, who was forced to marry according to social convention. The consequences of Delmira Augustini's choice, however, led to a truly tragic outcome.

The first lecture offered the Catholic Queen Isabela of Spain as the example of a visionary woman who encouraged Spain's age of discovery. De la Parra considered her to be the mother and godmother of criollo América, a woman who combined feminine graces with masculine virtues. The inheritors of her mission created a common heritage: women who lived in México City, Bogotá, Lima, Quito, Caracas, Buenos Aires and Havana shared a common legacy; it was as though they lived in the same city and could be sisters. But they would also have to overcome the negative aspects of this legacy which left them few models to follow other than that of wife, nun, or single women relying on the generosity of their families.

Working chronologically, de la Parra took up the case of Doña Marina, construing her as the power behind Cortés good fortune in the conquest of the Aztec empire. Several of the chronicles she read in preparing her talk acknowledged that Marina was the interpreter and mediator for Cortés, helping to uncover plots against him and his men in Cholula. But little had been written about Marina herself. One could only guess at what remained untold. Even Bernal Díaz del Castillo, who treated Marina kindly in his version of the history of the conquest, left much of her story unwritten. Chronicling military feats, victories, battles, and scenes of death and destruction drowned out the authentic voices of women. Their efforts were not as heroic, or worthy of epics. Their contributions were anonymous, reflected only in their children, their legacy in the mixing of the Indian and European races, as in the case of Marina as the mother of a mestizo child by Cortés and Nusta Isabel, a niece and grandchild of the last kings of Perú, and the mother of el Inca Garcilaso.

Marina had been sold as a slave by her mother and stepfather to other Indians, dispossessing her of her title and inheritance. But this only served to make her more adaptable. She was intelligent and spoke the language of the both the Mayas and the Aztecs, and she learned to speak Spanish, "as though she had been born in Seville" (Obra 481). She imagined Marina to be a charming and generous creature, an idealistic woman who welcomed change, a powerful presence, working as an emissary and translator. Yet after the birth of their son, Martín Cortés, and after conquering México, Cortés married the mother of his child to another soldier, Juan de Jaramillo. When Marina was reunited with the parents who sold her into slavery, she forgave them. De la Parra converted Marina into "a new Joseph sold by her brothers, a symbol of mercy" (Obra 483). This is the first example of de la Parra's use of biblical imagery to construct vivid analogies to make history come alive to her audience.

Bernal Díaz's chronicle was written in response to Cortés' own chronicler Gómera, another one of many chronicles in which women had been excluded. Bernal Díaz's chronicle was full of lively details, and Marina's role casts her as "the flower of a narrative that is not only historic, but something grander and more beautiful: a prose romance" (Obra 
484). True history, de la Parra concluded, was really about recording everyday details like the kind that enliven Bernal Díaz's chronicle, such as references to the soldier's nicknames and the colors of their horses. Other chroniclers had missed out by not reporting the work of women, an onerous exclusion, since "Excluding them, they severed one of the threads of life" (Obra 484).

Marina was only one example of Indian princesses who joined with Spanish conquistadors whose unions were dissolved. Such was the case of the Peruvian princess of Nusta Isabel, whose conquistador husband abandoned her and their six-year old son, the future author of the Florida of the Incas and The Royal Commentaries of Perú. El Inca Garcilaso de la Vega was born in Cuzco in 1539 to Sebastián Garcilaso de la Vega, who was related to the famous Golden Age poet from Toledo, Garcilaso de la Vega, and Isabel Chimpu Ocllo, a noblewoman and the niece of Huaina Capac and Atahualpa. When the Spanish conquistadors in Perú were ordered to marry, Garcilaso's father chose the Spaniard Doña Luisa Martel instead, marrying Isabel to one of his soldiers. De la Parra took up her betrayal as told by her son in his Comentarios Reales. It would be up to this mestizo poet to describe his childhood memories when he and his mother were reduced to being prisoners in their own house, eating whatever their servants could supply. All the while, Isabel conducted herself as a wife and Inca princess, keeping the household accounts on quipus, the Inca recordkeeping system of knotted ropes. Her son learned the history of her people, their legends and myths. In his memoir, the young Garcilaso recalled how he had no words of rancor for the father he loved and no bitter words for his step-mother. But his grief overwhelmed him when he remembered his mother, to whom he dedicated his book, "To my mother and lady, made more illustrious by baptismal water than by the royal blood of so many Incas" (Obra 489). The young Garcilaso traveled to Spain to reclaim his mother's land, but Isabel died during the process. Her son immersed himself in Spanish Renaissance life and wrote The General History of Perú. His Royal Commentaries, according to de la Parra, were his best work because they were based on the stories and legends told to him by obscure and forgotten Indian grandmothers. De la Parra ended the first lecture by admonishing her audience to reject neither the Spanish nor the Indian legacy that is a part of the American soul and an important aspect of their heritage. She also stressed the importance of oral tradition, since there were few records, letters or books about women in the archives during the conquest period. Traces of women's lives lived on through oral accounts.

Moving to the colonial period, the speaker discussed Sor Juana Inés de la Cruz in her role as a brilliant baroque poet and an unappreciated and stifled genius. She offered this Mexican nun as an example of the mystic intellectual, one of many who lived their lives in the convent. Convents played other important roles in colonial life. Nuns composed music and songs and performed when important personages such as the viceroy, the virreine, or the bishop visited. The Colombian Claretian nun Madre Castillo, like her Spanish predecessor, Teresa de Avila, was ordered to write her vita, and she too, wrote baroque poetry. The anonymous poet Amarilis was one of perhaps many literate women who lived in a patriarchal society and who wrote behind the scenes. She and perhaps many others like her were never given credit for their work. The anonymous colonial poet who called herself Amarilis wrote an epistolary poem which, according to de la Parra, should be more widely read in Spanish-speaking countries. "But perhaps her greatest charm is that she had the 
good taste to stay in the shadows, thereby offering a good example to the vain half talents who display their works" (Obra 501). She continued to tell the story of Amarilis: we only know that she wrote in 1621, she read the classics and she fell in love across the miles with Lope de Vega, whose fame was at its height. She wrote a poem in which she poured out her romantic longings to him, addressing him as Belardo. Lope responded with two letters that he never mailed to her and were later found in one of his books. The great Spanish literary critic Menédez Pelayo judged Amarilis to be one of the freshest and most charming colonial voices, but de la Parra insisted that when Amarilis' epistolary poem is compared to Lope de Vega's works, Amarilis' work is superior. During her lecture, de la Parra recited the poem to her audience, stopping here and there to explicate a line or to expand on a theme. She concluded that there were many other "Amarilis," that is to say, women who wrote, who lived their lives behind the grilles of their windows, who wrote their own poetic letter dedicated to a "Belardo" but who eventually gave their letter to someone who did not deserve it. And how many others, because they could not even write prose, never wrote at all? "It is to these women that I owe, no doubt, the almost mystical love for the old criollo tradition that is fast disappearing" (Obra 504).

While the male heroes of the revolution were acknowledged and revered, de la Parra wanted to emphasize the impact of the women who worked behind the scenes to make Venezuela a free nation A decree in 1872 expelled the Jesuits from Venezuela, which resulted in the closure of three convents in Caracas. Hundreds of women were literally thrown into the streets, and de la Parra told her audience how the inhabitants of Caracas came to the nuns' rescue. She deplored the decree of 1872, the cruel evictions of the nuns, women who had dedicated their lives to God, and she described how families converged on the plaza to take the nuns into their homes, where they constructed private alters and continued to live the cloistered lives of their order, praying, sewing, and cooking. The nuns were live repositories of three centuries of colonial life. De la Parra describes them as "lovers of silence who lived an interior life, and although it may seem like a contradiction, they were the precursors of the modern feminist ideal" (Obra 493). She admired and aligned herself with other women who chose the life of the mind.

During the past three centuries women had worked anonymously in the shadows, but the fight for independence changed that. By the late 18th century European ideological movements had found their way to Latin America. Once again, de la Parra insisted that there were many unknown and uncelebrated heroines who lived during this revolutionary time besides the well-known Pola Salavarrieta, Policarpa Salavarrieta (1795-1817). Also known as La Pola, she was a seamstress who worked on behalf of Colombian independence as a spy for the revolutionary forces. Shot to death by a Spanish firing squad, she became a martyr and national heroine. She also mentions her criollo female ancestors who contributed to the cause of the Venezuelan revolution. One of them was her forebear Mama Panchita, who had been exiled and left Venezuela with only the clothes on her back due to her political convictions.

Bolívar fell in love with María Teresa del Toro in Spain, married her when he was nineteen, and returned to live on his plantation in San Mateo. Eight months later María Teresa died of yellow fever, and the inconsolable Bolívar returned to Spain. In time, he inherited his uncle's vast fortune and traveled to Paris, where he fell in love with his cousin Fanny 
de Villars, who became his lover, friend, and counselor. He subsequently fell in love with Manuela Sáenz. De la Parra thought that many women had inspired and animated Bolívar. "From his black nursemaid Matea to Manuelita Sáenz, his last love, Bolívar could not live without the image of a woman to inspire him, to console him during his periods of melancholy, and to see through their eyes and look within to see his own genius" (Obra 514). Manuelita was very different from the quiet Teresa del Toro, and "represents the violent protest against woman's traditional servitude whose only future is the sometimes-closed door to matrimony" (Obra 524). She was a woman of action, a product of post-war thinking following the Independence movement. De la Parra tells how Manuelita was born in Ecuador, Argentina, or Perú, to a distinguished and wealthy family and while still a child she was married off to a wealthy Englishman she did not love. She presented Manuelita Sáenz as an untraditional woman whose vision was fired by the admiration of and protection for her lover. In 1930 de la Parra began corresponding with Vicente Lecuna, the foremost Bolívar historian. She planned to write a biography of Simón Bolívar, but she wanted to tell it from the point of view of his lover Manuela Sáenz. Although she accumulated a wealth of material and considered Sáenz to be a key force in the life of the Liberator of Latin America, due to her debilitating illness, the biography was never written.

Following his death, Manuelita was considered Bolívar's widow, and the Colombian government tried to oust her from Bogotá. She was determined to stay and got into bed with two pistols. Her maid accomplices were arrested, and she was eventually carried out of the house, still lying on her bed. She spent the last of her days in Paita, Colombia, supporting herself by making medicinal elixirs which her maid sold in the street. She renounced her inheritance, when her wealthy husband died, choosing to support herself, de la Parra reported. Simón Rodríquez, Bolívar's tutor, the Italian patriot Giuseppe Garibaldi and the Peruvian author Ricardo Palma all visited "La Libertadora". Proud of this title, she was a strong woman who crafted her own code of conduct and lived by it to the very end. De la Parra agreed that many would find Manuelita paradoxical, her behavior scandalous, and her moral code contrary to public opinion. She concluded her third lecture defending this heroine, an unconventional woman who flaunted society's rules so that she could be by the side of the romantic revolutionary she loved. Manuelita was an armed, crossdressing woman who fought by the side of her lover, who saved his life on at least two occasions. De la Parra passionately brought Doña Manuelita's uncompromising life to her audience's attention, and offered her as the last example in a list of heroic women who helped to shape the Americas.

As her illness progressed, she continued to read philosophy, history, and current literary criticism. Her energy lagging, with no cure for tuberculosis in sight, she recalled the pleasant days when she had the time and inspiration to write for hours. Palacios considers de la Parra's own life as the writer's third novel, calling it the story an adventure of a beautiful, talented woman who devoted herself to writing letters in the last few years of her life. In her letters, according to Palacios, the author became her own spectator. They reveal her disappointment in not being able to pursue formal studies, which would not have been an option for her. Throughout her life she compensated for her lack of university study by making up reading lists, attending lectures at the Sorbonne, corresponding with historians and other intellectuals, moving in Latin American diplomatic circles and traveling 
extensively. According to Palacios, her letters (Epistolario íntimo) are an unbound book, available for the reader who wants to bind it. The letters were witty and spontaneous, and in her remaining few years they represented her last heroic adventure: her description of her time spent in sanitariums, her striving for inner perfection and her correspondence with intellectuals, friends and family.

Her real gift, much underestimated and under-appreciated, was her use of subtle irony and her good-natured humor. She was misunderstood in her own day and was frustrated at having to defend her work, as when she had to explain what she had written about in Iphigenia. She continued to speak for herself in the press and in her letters. She expressed her vision for women's roles in society indirectly in Iphigenia and more forcefully in her lectures, aware that Latin American women had to struggle to attain a better position for themselves in society. In both Iphigenia and in her lectures, she criticized Venezuelan society and its values and mores, hoping for a future in which women would be educated, gainfully employed, and free to marry whomever they pleased, rather than to have the choice made by their family members or based on financial need. The lectures gave her the opportunity to come straight to the point, offering examples of how change could be achieved. After all, she had witnessed women being college educated, holding down jobs as well as being wives and mothers when she visited Havana and stayed with her companion Lydia Cabrera's family.

De la Parra's lectures provided an overview of women who had been instrumental but overlooked or forgotten by history. She used her fame and her celebrityhood to spread the word about the vital roles women played in Latin American history, focusing on women's activities and contributions in the formation of Latin American's soul. She reminded her audience that despite the constrictions of gender roles in the patriarchal societies in which they lived, women of the Americas from all walks of life could and did find ways to overcome these obstacles and set examples for alternative female identities and roles. Her own life was a case in point.

\section{Notes}

1. Translations from Iphigenia: The diary of a young lady who wrote because she was bored are from Bertie Acker's translation of the novel, University of Texas Press, 1993.

2. All translations from "Tres conferencias: influencia de las mujeres en la formación del alma americana," in Velia Bosch, Teresa de la Parra, Obra completas: (narrativa, ensayos, cartas). Caracas: Biblioteca Ayacucho, 1991.pp. 471- 528, are mine.

\section{References}

Acker, B.(1988) Ifigenia: Teresa de la Parra’s Social Protest. Letras Femeninas. 14.1-2: 73 74.

Lemaître, L. A. (1986) Between Flight and Longing: The Journey of Teresa de la Parra. Chicago: Vantage Press. 
Parra, Teresa de la. (1993) Iphigenia: The diary of a young lady who wrote because she was bored. trans. Bertie Acker. Austin: University of Texas Press.

-. (1953) Epistolario íntimo. Caracas: Línea Aeropostal Venezuelan.

-.(1991) Obra: (narrativa, ensayos, cartas). Ed. Velia Bosch. Caracas: Biblioteca Ayacucho.

Pantin, Y. and Ana Teresa Torres. (2003) El hilo de la voz: antología crítica de escritoras venezolanas del siglo XX. Caracas: Fundación Polar.

Palacios, M. F. (2001) Ifigenia: Mitología de la Doncella Criolla. Caracas: Fondo Editorial Angria Ediciones.

Pratt, A. (1981) Archetypal Patterns in Women's Fiction. Bloomington: Indiana University Press.

Mueller, R. (2012) "María Eugenia Alonso: The Modern Iphigenia Sacrificed to Society," The Woman in Latin American and Spanish Literature: Essays on Iconic Characters. pp. 60-73. McFarland.

---- (2012) Teresa de la Parra: A Literary Life. Cambridge Scholars Publishing: Newcastle upon Tyne, UK.

Resumen: Como heroína en la novela de su propia historia, la escritora venezolana Teresa de la Parra (1889-1936), fue una reconocida novelista y talentosa oradora pública, cuando en 1930 fue invitada a dar tres conferencias en las ciudades de Bogotá y Barranquilla (Colombia), y posteriormente en La Habana (Cuba). Las conferencias no fueron publicadas sino hasta 1961 en Caracas, por el crítico venezolano Arturo Uslar Pietri. Pietri y yo tradujimos las conferencias para el libro, Teresa de la Parra: Una vida literaria (Cambridge Scholars Publishing, 2012). Las Tres Conferencias: Influencia de las mujeres en la formación del alma americana describieron los importantes papeles que desempeñaron las mujeres durante las épocas de conquista, colonial e independencia en América Latina. Las Tres Conferencias representan su último trabajo. En la década de 1970, cuando los críticos comenzaron a aceptar los escritos de las mujeres por su valiosa contribución a la literatura, comenzaron a leer y a valorar el trabajo de esta escritora quien escribía sobre las heroínas femeninas.

En estas conferencias, de la Parra declaró ser una "feminista moderada" al resaltar los importantes papeles que desempeñaron las madres fundadoras en la historia latinoamericana y en la formación de su ética y cultura. Quería descubrir las dificultades que se habían impuesto a las mujeres a partir de la conquista de México. Mientras España conquistaba más del continente latinoamericano, las mujeres desempeñaban papeles importantes, pero de la Parra señaló que las historias de la mitad de la raza humana habían sido ignoradas por los historiadores latinoamericanos, quienes solían escribir sobre batallas y victorias en lugar de los sacrificios y los aportes heroicos que hacían las mujeres. Al recuperar las voces de las "madres fundadoras", la reina Isabela, Ňusta la Doña Isabela (la madre del Inca Garcilaso) Doña Marina, Madre Castillo, Policarpa Salavarrieta, Manuela Sáenz y sus contemporáneas Delmira Augustini y Gabriela Mistral, de la Parra creó una comunidad de heroínas.

Palabras claves: Teresa de la Parra - Feminista - Latinoamérica - Heroínas 
Resumo: Como heroína na obra que conta sua própria história, a autora venezuelana Teresa de la Parra (1889-1936) foi uma reconhecida romancista e palestrante talentosa, quando foi convidada para conduzir três palestras em Bogotá e Barranquilla, na Colômbia, em 1930 e depois em Cuba. As palestras não foram publicadas até 1961 em Caracas pelo crítico venezuelano Arturo Uslar Pietri e traduzidas por mim para o livro Teresa de la Parra: Uma Vida Literária (Cambridge Scholars Publishing, 2012). As Três Conferências: A Influência das Mulheres na Formação da Alma Americana (original: Tres Conferencias: Influencia de las mujeres en la formacion del alma americana)descreveu os importantes papéis desempenhados pelas mulheres durante as eras da Conquista, Colonial e da Independência na América Latina. As palestras colombianas representam seu último trabalho. Na década de 1970, quando os críticos começaram a valorizar a escrita feminina por sua valiosa contribuição à literatura, eles começaram a ler e a valorizar o trabalho dessa autora que abordava heroínas do sexo feminino.

Nessas conferências, de la Parra declarou-se uma "feminista moderada", ao destacar os importantes papéis desempenhados pelas mães fundadoras na história da América Latina e na formação de seu etos e cultura. Seu objetivo era descobrir as dificuldades que foram impostas às mulheres a partir da conquista do México. Conforme aEspanha conquistava os territórios do do continente latino americano, as mulheres passaram a desempenhar papéis importantes, porém, De la Parra aponta que metade dahistória da raça humana havia sido ignorada pelos historiadores latino americanos, que insistiam em recontar batalhas e vitórias , em detrimento do dos sacrifícios e os feitos heróicos das mulheres. Ao recuperar as vozes das “mães fundadoras", Rainha Isabela, Dona Isabela (mãe do Inca Garcilaso), Dona Marina, Madre Castillo, Policarpa Salavarrieta, Manuela Sáenz e suas contemporâneas Delmira Augustini e Gabriela Mistral, de la Parra criou uma comunidade de heroínas.

Palavras-chave: Parra - feminista - América Latina

[Las traducciones de los abstracts fueron supervisadas por el autor de cada artículo] 